This PDF is a selection from a published volume from the National Bureau of Economic Research

Volume Title: Emerging Labor Market Institutions for the Twenty-First Century

Volume Author/Editor: Richard B. Freeman, Joni Hersch and Lawrence Mishel, editors

Volume Publisher: University of Chicago Press

Volume ISBN: 0-226-26157-3

Volume URL: http://www.nber.org/books/free04-1

Conference Date: August 4-5, 2000

Publication Date: December 2004

Title: Development Intermediaries and the Training of Low-Wage Workers

Author: Lisa M. Lynch

URL: http://www.nber.org/chapters/c9959 


\title{
Development Intermediaries and the Training of Low-Wage Workers
}

\author{
Lisa M. Lynch
}

\subsection{Background Discussion}

During the latter half of the 1990s the unemployment rate in the United States reached a thirty-year low, a major influx of former welfare recipients entered the labor market, and employers in the high-tech sector demanded immigration reform to import skilled labor in order to meet their hiring needs. The time seemed ripe for increased job training in the United States, yet in spite of increasing returns to education and training over the last twenty years and high skill needs, the United States still seems to invest much less in postschool training than many other advanced industrialized economies. This chapter examines how various labor market intermediaries have intervened in the creation of training programs for low-wage workers to address the so-called "skills gap" of the past two decades. By describing the characteristics of different types of training intermediaries, it is hoped that some light might be shed on the potential longevity of these institutions, their capacity to achieve larger scale in the U.S. economy, and ultimately their ability to have a significant impact on the skill development of low-wage workers.

Before examining the role of labor market intermediaries in the provision of training to low-wage workers it is useful to briefly summarize what is known about the need for and supply of skills in the United States. In a nationally representative survey of U.S. businesses (see Black and Lynch

Lisa M. Lynch is the William L. Clayton Professor of International Economic Affairs and academic dean at the Fletcher School of Law and Diplomacy at Tufts University and a research associate at the National Bureau of Economic Research.

I would like to thank Richard Murnane for helpful comments on a previous version of this paper. 
[2001] for more details) 53 percent of nonmanufacturing and 46 percent of manufacturing employers reported that skills associated with the work of production or front-line employees increased over the period 1993-1996. As discussed in Lynch and Black (1998), this rising skill demand and the training associated with it appears to be related to the diffusion of computerization and the reorganization of work to increase employee involvement in problem solving and decision making. However, in this same national survey, more than one-third of U.S. employers reported that 25 percent or more of their workers were not fully proficient in their current job. In a separate survey of U.S. firms, the American Management Association reported in 1999 that over 38 percent of job applicants tested for basic skills by U.S. corporations lacked the necessary reading, writing, and math skills to do the jobs they sought. The share of skills-deficient applicants, the survey said, had increased from 22.8 percent in 1997. Even in the depressed labor market of 2003, the Association reported that 31 percent of the employers it surveyed thought the availability of skilled labor they needed to recruit was in scarce supply. ${ }^{1}$ It is not just employers who say that U.S. workers are not prepared for their jobs. Workers recognize this as well. For example, a recent study by Leuven and Oosterbeek (1999) found that one in four workers in the United States reported they were under trained. Finally, in an international survey of adult literacy, the Organization for Economic Cooperation and Development ([OECD] 1997) reported that almost one in five employed youth aged sixteen-twenty-five in the United States had minimal math skills compared to less than 5 percent of youth in countries such as Germany and Sweden.

Part of the reason why employers faced more skills-deficient applicants may have been because they had to hire further down in the distribution of skills given the overall strength of the economy during the latter half of the 1990s. So what have employers been doing in terms of addressing skill needs in the workplace? Research has shown (see Lynch [1994] for a review) that firm-provided training is much more likely to be obtained by more educated employees. This results in the creation of both a "virtuous" circle and a "vicious" circle of human capital accumulation. Individuals who acquire more schooling are also more likely to receive postschool employer-provided training, while those with minimal education find it extremely difficult to make up this deficiency in human capital once they enter the labor market. Workers in unionized firms are more likely to receive training than those in nonunionized establishments (see Lynch 1992; Lynch 1994). Large firms are more likely to provide training than small firms (see, for example, Lynch and Black 1998; Frazis, Herz, and Horrigan 1995), and, as shown in table 9.1, the firms that do invest in training are

1. See http://www.amanet.org/research/pdfs/2002_joboutlook.pdfhttp://www.amanet .org/research/pdfs/2002_joboutlook.pd. 
Table 9.1

Which workers get employer-provided job skills training? (percent of firms offering job skills training to indicated occupational category)

\begin{tabular}{lccc}
\hline Category of worker & All employers & Smaller employers & Larger employers \\
\hline Management & 50 & 46 & 80 \\
Professional or technical & 38 & 38 & 42 \\
Computer & 53 & 51 & 71 \\
Sales & 58 & 56 & 69 \\
Clerical & 35 & 33 & 48 \\
Services & 17 & 16 & 29 \\
Production & 36 & 34 & 47 \\
\hline
\end{tabular}

Source: Bureau of Labor Statistics Employer Training Survey, 1993.

more likely to provide it to their managers and professionals than to workers farther down the skills ladder. Because low-wage workers are typically employed in smaller firms and in service occupations, the figures in this table suggest that they are very unlikely to find additional support for skills upgrading from their employer. Only 16 percent of smaller firms offer training to service workers, while 80 percent of the largest employers offer training to their managerial workers.

Economists have discussed extensively why, in spite of apparently high returns to employer provided training, employers may not provide training to meet all skills needs. A firm's decision to invest in workforce training, especially more general training, is likely influenced by the characteristics of the workers they employ. Employees who are perceived to have higher turnover rates, such as low-wage and low-skilled workers, are less likely to receive employer-provided training. In addition, training itself may contribute to employee turnover: if new skills are of value to other employers, then firms risk having their trained employee hired away (the poaching or "cherry-picking" problem). Therefore, investments in nonportable firmspecific training are more attractive to firms than are investments in general training unless employers can find some ways to "capture" their investment in general training. If firms invest in general skills of workers and workers then leave a firm, employers may end up investing in a suboptimal level of training.

In addition, smaller firms may have higher training costs per employee than larger firms because they cannot spread fixed costs of training over a large group of employees. The loss in production from having one additional worker in off-site training is probably much higher for a small firm than for a larger one. Smaller firms are also less likely to have developed extensive internal labor markets that allow them to better retain and promote employees within a firm.

But training is a different type of investment decision than the one to invest in new physical capital. There are two players in the training deci- 
sion - the employer and the worker. Therefore, even if employers were reluctant to invest in general skills training, we would not necessarily see underinvestment in training in the economy as a whole. If capital markets were perfect so that workers could borrow to finance more general training, if the government subsidized general training, or if workers accepted lower wages during training spells, training would still occur. However, capital markets are far from perfect, and workers differ from employers in their attitudes toward risk and time horizons. As a result, there may be a market failure in the provision of general training and the proportion of workers trained in more general skills.

Theoretical work by Stevens (1994) and Acemoglu and Pischke (1998, 1999) has reexamined the issue of market failure in the delivery of training in the context of imperfect competition in the labor market. More specifically, Acemoglu and Pischke show how a firm can exhibit ex post monopsony power, and, as a result, workers decide not to invest in general training because they realize that part of the return will be appropriated by the firm. A key feature of their model is that workers could end up not investing in general training even if they were not credit constrained and firms might underinvest in training as well. Acemoglu and Pischke (1998) argue that, depending on institutional features of the labor market, there may be multiple training equilibriums - low training and high quit rates or low quit rates and high training with the United States representing a high quit rate and low training equilibrium and Germany and Japan representing a low quit rate and high training equilibrium. They propose a variety of possible policy solutions to raise the equilibrium level of training in a noncompetitive labor market. These include training subsidies to employers, government-provided training, and training subsidies supplemented with regulation of the provision of training. They argue that subsidies on their own may result in a windfall gain to employers if the government ends up paying for training that employers would have provided anyway. Government training programs that do not involve employers in the development and updating of curriculum could become irrelevant in meeting the needs of employers. However, they argue that subsidies with regulation where the quality of training programs was monitored and the skills provided were certified could minimize this risk. But they do not discuss the institutional structure that might provide this monitoring and skill certification in the case of the United States.

Booth and Chatterji (1998) show that unions, in the context of firm ex post monopsonistic power, can increase social welfare by counterbalancing the firm's ex post monopsonistic power in wage determination. As a result, local union-firm wage bargaining ensures that the post-training wage is set sufficiently high to deter at least some quits so that the number of workers that the firm trains is nearer the social optimum. The perceived longevity of a union provides the union with critical power to enforce multi- 
period contract agreements, reducing the possibility that an employer reneges on wage increases linked to human capital investments ex post.

Empirically we see (see Lynch and Black 1998) that unionized establishments in the United States are more likely to provide training to workers than nonunionized businesses even after controlling for a wide range of firm and worker characteristics. So labor market institutions, especially unions, can play a potentially important role in ensuring that there is not a market failure in training and move a country in the direction of a high training equilibrium. But even in countries with high unionization rates, the existence of unions alone does not appear to be a sufficient condition to overcome the potential of a market failure in training. As discussed in Lynch (1994), many countries, such as Sweden, Japan, and Germany, have pursued very different yet ultimately successful institutional systems to overcome the potential market failure inherent in firm-based general training. For example, business, labor, and government in Germany have designed an institutional training system characterized by three featurescodetermination, coinvestment, and certification of training. These features, along with enforcement pressure provided by chambers of commerce (see Soskice [1994] for a more detailed discussion of this) to minimize "unfair" poaching of workers by employers, have produced a high training equilibrium in Germany. There is substantial coinvestment in training in Germany because apprentices in Germany work at substantially lower wages during their apprenticeship. At the same time, employers contribute large sums to apprenticeship programs and the government funds extensive classroom training. The content of apprenticeship programs in Germany is codetermined with unions, employers groups, and the government to ensure relevance and generality of skills. Finally, the certification of skills makes it worthwhile for young workers to accept lower wages, maintains uniform quality standards, and makes identifying skills much easier for employers. In addition, German employers have created incentives for youths who do not obtain a university degree to perform well in secondary school by linking placement into "better" apprenticeships with their school record.

Whether or not Germany can continue with this model remains to be seen because the German model depends on a broad consensus among the social partners that has been increasingly challenged in the context of unification. But in the United States, with less than 10 percent of all workers represented by unions in the private sector and little tradition of labormanagement-government cooperation, the potential for business, labor, and government to intervene a la the German model and push the economy toward a higher training equilibrium seems bleak.

So how might we increase the amount of postschool training provided beyond what single employers may be willing to do (in either a unionized or nonunionized context)? Are there institutions, in addition to unions, in 
the United States that may be able to play a role in solving this market failure in the delivery of training and move us to a higher training equilibrium? In particular, how could these institutions take on the characteristics that unions or labor market systems in Germany and Japan have historically done to ensure a higher training/wage equilibrium?

I would like to posit that there are several features that any such institution would need to acquire if they are to succeed in addressing the current skills issues facing the U.S. economy. If one of the ways in which unions raise the equilibrium level of training is through enforcement of long-term agreements between employers and workers, then other types of labor market intermediaries would need to be able to negotiate with employers in a similar way. This requires that they are sufficiently powerful to engage in such discussions. Now in union models we typically think of unions having bargaining power because they can organize workers to withhold their labor. However, the sources of power for labor market intermediaries that are based outside of the workplace are not so clear. Potential sources of power for these institutions might include the ability to influence public opinion or consumer buying power or political influence that in turn could bring pressure to bear on employers. In addition, when unemployment is low, as it was at the end of the 1990s, labor market intermediaries have another possible leverage point - their ability to identify and screen new workers from social networks that were not part of employers' traditional recruiting networks. Finally, regardless of the state of the labor market, with welfare reform there is a rising demand from those who have been disconnected from the labor market for a considerable period of time to get reconnected. So the ability of intermediaries to bridge asymmetries in information in the labor market could increase their bargaining power.

In order to avoid the problem of paying for training programs that private-sector employers would have been willing to do anyway, these institutions would also have to have the capacity to design training strategies that go beyond individual employers. To do this they would need to be well connected with employers to ensure that training is relevant and portable.

Employers' perception of the permanency of the intermediary will also affect labor market intermediaries' ability to successfully negotiate with local employers and government. A nonunion organization that wants to be a training intermediary will need to be able to establish a reputation that it is not an institution that might be focused on training issues today but something quite different tomorrow. If the primary basis of its ability to negotiate with local employers is a tight labor market then when demand conditions change they run the risk of not surviving. Therefore, they would need to have a steady and predictable source of funding that would serve to enhance their negotiating power as they bargain with local employers to reach a new training equilibrium. This funding should be sufficient to al- 
low the organization to grow so that it can benefit from returns to scale in the provision of training (just as larger private-sector firms do).

In sum, in order to effectively raise the training equilibrium of an economy, an intermediary would need to act as a broker between employers and workers in the provision of skills, have the ability to enforce contractual agreements over multiple periods, be able to monitor the quality of training provided, and, finally, have the capacity to go to scale. To increase the probability that training intermediaries can raise the equilibrium level of training, they need to be structured in such a way as to ensure that there is codetermination, coinvestment, and certification of training. The next section of this chapter identifies some examples of how labor market intermediaries in the United States have tried to create at the local and national level a new training system targeted at low-wage workers.

\subsection{Examples of Emerging Training Intermediaries for Low-Wage Workers}

The role of third party intermediaries in the labor market to provide training is certainly not something new - there are numerous for-profit training providers that market their ability to provide skilled training and/ or skilled workers to a firm. In addition, under the federal Workforce Investment Act, workforce development boards have been created all over the country to implement federally funded training programs through partnerships with labor, management, and government. Many of these boards have built upon successful partnerships that were previously formed in local private industry councils. However, what I am focusing on in this chapter are primarily not-for-profit social institutions (some have called them development intermediaries) that have attempted to establish new partnerships focused on raising the skills equilibrium in a particular geographic area or for a demographic group rather than for the needs of a single specific employer. This is not meant to be an exhaustive list of all of the many such efforts currently under way in the United States. Instead, I have tried to identify emerging institutions that are geographically diverse; have established different types of partnership relationships between community groups, training providers, employers, and government; have used different sources of funding; and have impacted varying industries.

\subsubsection{Union-Management Collaborative Efforts}

There are numerous examples of union-management collaborative efforts to increase training (see, for example, American Federation of LaborCongress of Industrial Organization [AFL-CIO] Working for American Institute 2000). What is special about the following examples is how they have created unique sectoral and regional partnerships between labor and 
management to raise skills standards. These are all multiemployer partnerships with either a single or multiple unions. I have chosen quite different sectors for my examples - the electrical contracting sector, the hotel and hospitality sector, temporary workers in Silicon Valley, and the garment industry. These are sectors that potentially could provide opportunities for currently low-skilled workers to find jobs with wages and benefits that can support a family. They are also sectors undergoing tremendous change. In electrical contracting and the temporary help business in Silicon Valley, skill needs are being driven by new technologies; in the hotel industry, skill needs are being driven by competitive pressure from nonunion hotels; and in the garment industry, the ability to maintain jobs within the United States with global competition will depend on the ability of employers to use innovative new technology.

\section{The IBEWINECA Joint Apprentice and Training Committee for the Electrical Contracting Industry of Greater Boston}

This program was established in 1947 as a quasi-independent organization and qualifies under Internal Revenue Service (IRS) rules as an educational institution. This is part of a broader national program. The Boston program is funded through several collective-bargaining agreements between the Boston Chapter of the National Electrical Contractors Association (NECA) and Local Union 103 of the International Brotherhood of Electrical Workers (IBEW). It represents approximately 150 major contracting firms and over 4,000 skilled workers. This program is unique because it is responsible for the selection, education, and training of all apprentices entering the units covered by the collective-bargaining agreements of these 150 firms. It is also a collaborative effort in an industry that has been transformed by technological change but one that represents a potentially rewarding career path for currently lower-skilled individuals. This center has all of the features described previously as critical to a successful training system-coinvestment, codetermination, and certification. The program has clearly established a reputation for longevity, and its funding stream is relatively predictable.

\section{Working Partnerships USA}

Working Partnerships was founded in 1995 as a collaboration between community-based organizations and the South Bay AFL-CIO Labor Council in San Jose, California. Its objective is to act as a labor market intermediary in the area of temporary help workers. They have established the Temporary Worker's Employment Project (see their website at http:// www.atwork.org for more details) that is focused on assisting temporary workers to find jobs at better wages along with creating a skills standard for contingent workers in the clerical field. The project is made up of two components: together@work is a membership-based organization for contin- 
gent workers that provides portable benefits and financial services, and solutions@work is an employee-governed staffing company that trains and places clerical workers throughout Silicon Valley. An example of their partnership efforts is their collaboration with Service Employees International Union (SEIU) Local 715 and West Valley Community College to provide skills certification, job rights training, and job placement for temporary workers seeking clerical employment with the county of Santa Clara. As part of this effort they administer portable benefits and provide ongoing job referrals to participants. Their funding sources have included private foundations, such as the Charles Stewart Mott Foundation; union support; and fees they charge to private-sector employers. They have also been very active in reaching out to social institutions in the area to support their activities. For example, they staff the Interfaith Council on Religion, Race, Economic and Social Justice in San Jose and have been involved in local private-industry councils. While their efforts have focused on workers in the Silicon Valley, they have partnered with national organizations such as the National Interfaith Committee on Working Justice. Again, this organization's training development strategy includes the three features of coinvestment, certification, and codetermination. Their institutional structure is unusual due to the decision to not only partner with local employers but also to become an employer as well. While the crash of the hightech sector has had a large impact on the local employment conditions, it appears that the strategies of this organization remain unchanged, and there are even discussions to try to create a national version of this organization. The charismatic head of this organization, Amy Dean, left her position as executive officer of South Bay Labor Council in the summer of 2003 to go to Chicago and create a national version of this organization. It will be interesting to see how the organization responds to this change in leadership.

\section{The San Francisco Hotel Partnership}

In 1994 a group of the major hotel chains in San Francisco banded together to form the San Francisco Multiemployer Group and negotiated a new labor contract (called a Living Contract) with the local union (Hotel Employees and Restaurant Employees [HERE] Local 2) to improve service and productivity in order to better compete with nonunion hotels. Stuart Korshak (2000), who was the general counsel hired by the hotel group to help them negotiate this agreement, argues that a critical component of the 1994 contract was the training program created within the agreement. The training program is focused on improving communication skills between workers and guests and workers and managers along with improving critical thinking skills, team building, problem solving, English as a second language, and craft-specific technical skills. It is sixty times larger in scope than any previous joint training program in the hotel industry in 
San Francisco and is funded jointly by the unions, management, and funds from the state of California. Union and management jointly designed the curriculum. Korshak (2000) states that this was critical to overcome fears among some employees that the program was merely a way for management to weed out workers or just some fad. Finally, the training of workers within the hotels was extended to the hiring hall to raise skills for banquet servers, including classes in French service, wine appreciation, and food carving along with training in sanitation and safety issues. The training component of this agreement was an important complement to another unique dimension of this agreement, which was greater employee involvement. At the end of the five-year contract, the hotels and unions, as described by Korshak (2000), have gone from a confrontational relationship to a partnership based on mutual gains. Again, this is a good example of an institutional structure that is characterized by coinvestment, codetermination, and certification of skills. The fact that the contract was recently renewed and kept these unique features suggests that this increased investment in workers' skills will remain a permanent feature of the hotel industry in San Francisco. It will be interesting to watch, however, what happens if employee turnover is such that the partnership finds itself providing much of the training for the nonunion hotels as well.

\section{The Garment Industry Development Corporation}

This is a nonprofit consortium established in 1984 by labor, industry, and government focused on improving the competitiveness of the apparel industry in New York City. In the area of training, the Union of Needletrades, Industrial, and Textile Employees (UNITE), representing over 30,000 workers, in collaboration with hundreds of local employers, has established the Fashion Industry Modernization Center located in the garment district in New York City. Its facility includes the latest in computerized sewing machines, state-of-the-art presses, and a computer lab carrying Computer Aided Design and Computer Aided Machining (CAD/CAM) software. More specifically, it offers skills training for dislocated sewing machine operators as well as English as a second language and health and safety instruction. A unique feature of this training center is that it trains not only workers in the industry but also garment contractor and manufacturers in the latest techniques and innovations. In this way the center hopes that it will train employers in techniques that will ensure that they will be able to compete successfully and therefore retain jobs in the city. Again this is a good example of the three Cs, with financial support coming from labor, management, and government. However, what is unusual in this collaboration is the nature of the codetermination of the training content. When we usually think of codetermination, we think of employers being involved in curriculum design to ensure that the skills content of 
courses is sufficiently up to date to meet their needs. Instead, in this example the training center is focused in part on educating employers about technology options that will enable them to remain competitive.

\subsubsection{Community Based Organizations}

Perhaps the most important new form of training intermediaries has been the rise of community-based organizations taking on activities in economic development. In particular, more interfaith organizations have become involved in efforts to increase the training opportunities provided by local employers for low-wage workers. The interfaith organizations are place-based, and so they build upon a preexisting institutional structure. But this structure has not historically been involved in economic development issues. Therefore, a first challenge faced by these organizations is to develop the human capital within the organization to allow it to prepare a strategy for economic development issues, such as training. If they "contract out" this expertise, they run the risk of losing an important source of their power-broad-based grassroots support. Their source of leverage is their diversity and ability to bring together a broad political coalition. A challenge for these organizations, however, is to maintain support (both financial and public) for an issue like training that may not generate the same sense of urgency as housing or school quality. In addition, some of the organizations have struggled to create a governance structure that ensures that the institutional partnerships that they broker can deliver a training system that is characterized by coinvestment, codetermination, and certification. The examples in the following include interfaith communitybased organizations along with other examples that have been chosen for the sectors they target or unique sources of funding.

\section{San Antonio, Texas Industrial Areas Foundation}

A considerable amount has already been written about the Industrial Areas Foundation (IAF), especially its experience in Texas. As discussed by Ernesto Cortés (1994), the IAF is a national network of broad-based, multi-ethnic interfaith organizations in primarily poor and moderateincome communities. It was created over fifty years ago by Saul Alinsky, and it provides leadership training for nearly forty organizations representing over 1,000 institutions and one million families principally in New York, Texas, California, Arizona, New Mexico, Nebraska, Maryland, Tennessee, and the United Kingdom. One of the best-documented experiences of the IAF and training for low-wage workers is Project QUEST in San Antonio, Texas. Project QUEST grew out of a new social compact among employers, workers, and the community at large. It was engineered by two IAF organizations - Communities Organized for Public Service (COPS), one of the oldest and most established IAFs, and Metro Alliance. Brett 
Campbell (1994) describes this compact as a new kind of labor market intermediary.

As Campbell (1994) discusses, the IAF, through its involvement in Project QUEST, “operates as a mediating institution to bring families back into relationships with employers, training institutions and social service providers." This has a certain ring of "codetermination." In addition to this structure that provides codetermination, the IAF's philosophy and experience in Project QUEST emphasizes coinvestment in training with workers contributing "sweat equity," state and local governments providing funds, local employers committing to 650 jobs, and employer involvement in curriculum design and funding support for training programs at local community colleges. Finally, in the studies by Campbell (1994) and Osterman and Lautsch (1996), it is clear that Project QUEST focused much of its attention on redesigning the role that community colleges played in the local labor market. This included certification of training programs as seen, for example, with a customer-service-accredited certificate program they developed in conjunction with a local community college and the American Institute of Banking.

However, before concluding that the Texas IAFs are the new magic elixir for worker voice and worker protection, it should be pointed out that there have been difficulties. Mark Warren (1996), in his detailed study of the Fort Worth IAF, points out that the Fort Worth IAF has had difficulty in recruiting large numbers of affluent whites in mainstream denominations to work cooperatively with leaders of African-American and Hispanic communities. In addition, in their evaluation of Project QUEST, Osterman and Lautsch discuss how employers have supported Project QUEST by providing input on training programs development and forecasts of future staffing needs. But they argue that few employers have made dramatic changes in their hiring practices in response to Project QUEST. In addition, unstable government funding has at times undermined the sense of permanency of Project QUEST. Although employers were "coinvesting" by making employment pledges, the length of Project QUEST training programs meant that employers found themselves making a pledge of a job placement that would not occur for two years. Project QUEST has also struggled to attract clients given Texas's "work first" mandate that stresses work over skills training.

Osterman and Lautsch (1996) also raise concerns about how successful the program would be in meeting the needs of displaced workers from Kelly Air Force Base in San Antonio, which closed in August 2001. On this front, the IAF worked to broker a deal whereby in April of 1997, Boeing signed a twenty-year lease (four five-year options) for 1.3 million square feet of space at Kelly to create a world-class maintenance and modification center for large, primarily military aircraft. Part of the agreement between the city of San Antonio, the Greater Kelly Development Corporation, and 
Boeing included $\$ 7$ million of warehouse improvements for the facilities that Boeing occupies that are Boeing-specific upgrades on top of another \$25 million of general improvements. In addition, incentives were included to reward Boeing for the number of Kelly workers hired and the wages and benefits paid to them.

As part of the master plan to redevelop the Kelly Air Force Base, a hightech training center has also been established. In July 2002, the Alamo Community College District (ACCD) opened the Advanced Technology Center (ATC) at the former Kelly Air Force Base. This training center partners the ACCD with Lockheed-Martin, Boeing Aerospace, Standard Aero, Chromalloy, Pratt \& Whitney, Defense Aerospace Industry, a range of industrial technology (IT) companies, and ARC Information Assurance Institute. The center provides customized training taught by faculty from the ACCD colleges in the areas of aerospace industries, computer technologies and e-commerce, and telecommunications. The center is projected to train 2,000 people on site each year, with an additional 800 trained via distance learning. One of the four community colleges that make up the ACCD is St. Philips College. St. Philips College, a historically black and Hispanic serving institution, was the first Texas community college to be designated a One-Stop Workforce Center. It serves to link welfare recipients and displaced Kelly employees to area education and employment opportunities. It has worked very closely with the IAF to revamp its course offerings to meet the needs of local workers and employers and is a good example of a transformed labor market institution.

\section{Jane Addams Resource Corporation}

This not-for-profit community development organization was founded in 1985 to promote retention and growth of local metal working firms on Chicago's north side. One of their primary activities has been their Metalworking Skills Training Program to provide literacy and technical training for low-wage workers, but they also have programs in computer skills training and adult basic learning. As described in a report for the National Governors Association (see Brown et al. 1998), this training program is undergoing an extensive evaluation and assessment effort. While this program appears to have been highly successful, it is still relatively small. More generally, the challenge for many community development organizations is how to broaden their impact and achieve greater scale. But this organization has tried to achieve larger scale through a recent collaboration with other Chicago-based community-based training providers. In 1999 the U.S. Department of Labor (DOL) funded a two year one million dollar demonstration project (this was one of ten such projects funded by the DOL) in Chicago called the Regional Manufacturing Training System (RMTS). This project links the metal working program training provided by the Jane Addams Resource Corporation with wood working training 
programs developed by the community-based organization Greater West Town Project and manufacturing training for machine operators, electroplaters, and industrial maintenance mechanics developed by the Chicago Manufacturing Institute and targets over 300 workers in Chicago. There is active involvement in standards and curriculum development by local employers, local government, community colleges, and universities in the RMTS. But the real challenge for this new organization will be its ability to become self-sustaining in the face of federal cuts in job training. How they do this will be informative of the issues facing other CBOs as they try to go to scale.

\section{National Urban League}

One community-based program that has gone to scale and has a welldeveloped national presence is the National Urban League (NUL). Founded in 1910 with affiliates in over 100 cities in thirty-two states and the District of Columbia, the mission of the NUL has been to enable African Americans to secure economic self-reliance, parity and power, and civil rights. Local affiliates have organized and developed numerous job training programs over the years. For example, with technical assistance from companies such as IBM, the San Diego Urban League has established the Training Institute, which provides training programs for careers in computing such as clerical and administrative assistants, electronic assemblers, mechanical assemblers, systems coordinators, systems maintenance analysts, technical support specialists, installers, quality assurance specialists, and equipment testers. The programs range from 120 to 480 hours long and are specialized for beginner, intermediate, and advanced learners using a mixture of computer-based and instructor-led training. In addition to training, the San Diego Urban League has an extensive employment service that places over 2,000 people annually in unsubsidized employment. The league has worked with local employers to develop employment networks, get their involvement in training design, and even conduct mock interviews. The sources of funding for the San Diego Urban League include local employers, foundations, and local government. So the San Diego Urban League's institutional structure has covered the three Cs of training. But the NUL has been able to do what few other community-based groups have done and that is to pull together local efforts into a national strategy to share and build on successful programs. Through this coordination the NUL has built a powerful political base that helps it negotiate workforce development issues at the local and national level.

\section{Annie E. Casey Foundation Jobs Initiative}

One of the important funding sources for many not-for-profit training intermediaries has been foundations. This support has been critical for the creation and survival of many of these organizations. For example, in 1995 
the Annie E. Casey Foundation began an eight-year six-site $\$ 30$ million demonstration project to help low-income residents in designated neighborhoods find jobs that paid family-supporting wages. All of the six sites (located in Denver, Milwaukee, New Orleans, Philadelphia, St. Louis, and Seattle) are managed by what the foundation calls "entrepreneurial intermediaries." The general philosophy of the foundation's efforts appears to be a catalyst to bring together employers, elected officials, communitybased organizations, low-income residents, and other stakeholders in the design and creation of new job-related initiatives.

By 2003, this jobs initiative had served over 17,000 people of which 40 percent were single parents, 35 percent had less than a high school degree, 20 percent did not speak English as their primary language, the median income for participants who had ever worked was $\$ 6,000$, and 45 percent received public assistance at the time of enrollment. The model is a sectoralbased approach in that the intermediaries target specific sectors of the local economy in which they develop employment and training opportunities. The sites have varied greatly in the composition of these managing intermediaries. The two examples in the following have been chosen because of the different governance structures chosen, the diversity of the targeted participants, and the range of sectors for placement.

The Milwaukee example is typical of the problems facing many large urban areas. When this jobs initiative began in 1997, the city's unemployment rate was around 3 percent, but in the poorest neighborhoods it was 23 percent, with many long-term unemployed. The Milwaukee Jobs Initiative chose to partner with an existing training program, the Milwaukee Graphic Arts Institute (MGAI) to develop training for low-wage workers with no previous experience in an industry that has been rapidly transformed by computerization. As described in an initial report by the Annie E. Casey Foundation (2000), the Milwaukee Jobs Initiative worked quickly to get money from agencies receiving Temporary Assistance for Needy Families (TANF) grants to fund and implement training programs for entry-level workers. This allowed MGAI to recruit more broadly, provide customized training, and get people into jobs quickly. As a result, MGAI was able to establish a track record that they used to approach new industries and employers. They also worked closely with the local private industry council to streamline its funding process to get resources into training more quickly.

The Milwaukee Jobs Initiative has also been active in two other sectors-manufacturing and construction. In manufacturing they are working with the preexisting Wisconsin Regional Training Partnership (a consortium of unions and employers) to develop vocational education, including the provision of instructors for on-the-job training from the Milwaukee Area Technical College. In construction, the Campaign for a Sustainable Milwaukee has opened a construction workers' center in a neigh- 
borhood church where job seekers can meet contractors and union officials to find out about training and other support services to help them build a career in the construction trades. This effort is especially focused on recruiting more African Americans into this sector.

The New Orleans Job Initiative had a difficult start and has some of the greatest challenges of the six sites. In fact, the demonstration project almost fell apart initially. In 1997 the New Orleans Jobs Initiative faced an organizational crisis. On the one hand, they realized that in order to succeed they needed to include more representatives from major businesses on their governing board. But, on the other hand, because the initiative was a grassroots effort, how could community control be maintained if the board was expanded to include employers? What lurked behind this discussion was, according to the Abt Associates and the New School for Social Research (1999) initial evaluation report, a long history of racially charged tension between representatives of the impact community and the city's business community. This issue was ultimately resolved by increasing employer representation on the board but giving veto power to three principal community groups over all board policies and actions. Because of the delay in resolving governance issues, this site has only just begun to organize its training activities.

They are targeting four sectors - construction, manufacturing (in particular, machining), health care, and office sectors. Employee referrals come from community-based organizations. Once recruited, enrollees receive technical skills training at a local community college, which in turn works closely with employers to design curricula to meet their skill needs. In the construction area, the initiative is developing a program with community groups, contractors, and a labor union to recruit job seekers and place them in a 100-hour training program and then in jobs paying $\$ 7$ to start. In the area of machinists, the program has developed a training program for entry-level workers where an employer will provide a six-month training program. At the end of the training, the individuals are placed in jobs at other machine shops. Community organizations have been engaged to help workers with transportation and other social supports. One of the innovations of this program has been a twenty-one-day job-readiness program that focuses on the development of "soft skills" of work (such as coping with stress and work attitude) to complement the technical training.

However, there have been tensions in the relations between the local private industry council and the New Orleans Jobs Initiative. The private industry council decided that the training models the New Orleans Jobs Initiative developed did not meet federal funding guidelines. This affected funding for the New Orleans Jobs Initiative. In addition, the initiative had difficulty early on with the local community college it was working with to provide the type of technical skills training the New Orleans Jobs Initiative 
clients needed and the time constraints they faced. Only two people completed the manufacturing program in the first two years of the initiative. However, as reported in its most recent update, ${ }^{2}$ the number of participants who have completed the machinist program is twenty-five, and fifty have completed the construction program.

Clearly the New Orleans Jobs Initiative has struggled and is a good example of the tensions underlying the concept of codetermination. It is not necessarily easy to get all parties to agree to codetermine the content of programs if there is not sufficient trust among all the partners. The city of New Orleans has also created a new Office of Workforce Development that will manage and administer federal training funds. Establishing a successful relationship with this new office will be critical for the survival and ultimate success of the New Orleans Jobs Initiative.

\section{WorkSource Staffing Partnership, Inc.}

While this chapter has focused on not-for-profit efforts in training programs, there has been another avenue in which not-for-profit institutions have tried to expand the development of training programs targeted at lowwage workers. This is through the use of federally sponsored Community Development Financial Institution Funds that link low-income areas with financial capital to spur economic development. An example of this activity is WorkSource Staffing Partnership, Inc. in Boston, Massachusetts. The initial funding source for this for-profit firm was venture capital from the Boston Community Venture Fund, which was created as part of the federally sponsored Community Development Financial Institutions Fund. Established in 1995 as a for-profit firm, WorkSource Staffing Partnership, Inc. has developed partnerships between community-based organizations and employers based in Boston. The focus of this firm has been to help underemployed low-wage workers and former welfare recipients obtain job training and access to better career paths. At the same time it has provided local employers in a tight labor market the ability to identify potential employees outside their traditional recruiting networks. The success of the firm depends critically on its ability to establish a reputation for identifying and preparing motivated and work-ready employees. They do this by working closely with community-based organizations to identify motivated individuals who they then help obtain appropriate training and employment. WorkSource Staffing Partnership, Inc. also provides follow-up support for child care, transportation, housing, and personal management issues. Their employer partnerships have been primarily in the health care sector, such as the Joslin Diabetes Center and Partners Health Care. In this

2. See http://www.aecf.org/initiatives/jobsinitiatives/neworleans.htm; accessed November $14,2003$. 
case, a not-for-profit social investment fund supported the creation of a for-profit firm to deliver training to economically disadvantaged workers. By focusing on the health care sector, which has continued to grow even during the most recent recession, this organization has established a successful track record of working with welfare recipients and successfully placing them in the health care sector. In fact, Partners Healthcare has decided to privately fund its Project RISE (Reaching Individuals Striving for Excellence). In the longer term it will be interesting to see how this firm is able to continue to serve its current client base compared to other more traditional for-profit placement firms and not-for-profit community-based organizations. Will its for-profit status drive it away from low-wage workers once not-for-profit funding support is gone? So far this does not seem to be the case.

\subsection{The Future of Emerging Training Intermediaries}

As outlined in the examples detailed previously, one of the biggest challenges to the capacity of these emerging labor market intermediaries has been funding. For those programs supported by joint labor management agreements, funding for the training programs will likely be determined in large part by the economic fortunes of the sector for which the training is done. For many of the programs examined in this study that are sponsored by venture capital money or private foundation support, the hope is that once the programs are up and running that alternative sources of funding would be identified. These would include employers in the private sector paying a fee for the ability to recruit skilled work-ready individuals outside their traditional networks or state or federal funds to support workforce development of low-wage workers.

However, as these programs are pushed to become more self-sufficient and depend primarily on private employer funding, will they be able to maintain their focus on the most disadvantaged workers? If they instead rely on federal funds to maintain their activities, they run the risk of competing for increasingly scarce funds given a special problem with federal funding formulas. A state's share of funds from the Workforce Investment Act is heavily based on unemployment rates and concentrated joblessness. This works against a state like Massachusetts, for example, that is more plagued by earnings shortfalls among the working poor than by pockets of high unemployment. Second, in principle, the Workforce Investment Act allows states to target not only unemployed but also low-wage working individuals for training. But if we look at the inflation-adjusted federal training funds per civilian labor force member over the period of 1993-1999, we see that this number has fallen almost 20 percent (see Donahue, Lynch, and Whitehead 2000). So the federal government is an unlikely source for 
increased training funds, especially when economic conditions are relatively good. More federal funds are available when the economy goes into a recession, but this is also the toughest time to place those with the lowest skills into employment.

As a result of this trend in federal funding of training, what states chose to do will have an important impact on the eventual success of these different types of intermediaries. It will be up to individual states to decide whether they will allocate additional funds for the creation of a workforce development system that will meet the needs of the working poor along with those without employment. The most recent economic downturn has put enormous pressure on state-funded workforce development programs as requirements to balance state budgets resulted in substantial cuts in state funding. This will mean that many of the organizations described in this chapter will need to engage in the political process to ensure that funds are allocated to their activities. Their success will be driven by their political power and reputation, the success of current activities, and the general economic climate of the state/community they are in.

A second issue is employer involvement. While it is critical to ensure that there is employer involvement in these emerging intermediaries, there is also a tension about how much of a role employers should play in the governance of these institutions. In the Abt Associates and the New School for Social Research's (1999) study of the Annie E. Casey Foundation's six-site jobs initiative, there is considerable discussion of reasons why employers were willing to participate in these programs and why they weren't. Participation was usually driven by employers playing a "leadership" role on advisory boards or a "placement" role where they are recruited as customers of the jobs initiative. In tight labor markets it is easier to attract employers into a placement role, but this has not always been so. Stereotypes of the impact communities persist, and one wonders about the fortunes of some of the programs described in this chapter as the economy suffers an economic downturn.

This chapter has tried to outline some of the basic characteristics of emerging intermediaries in the provision of training to low-wage workers (see table 9.2). ${ }^{3}$ The examples cited are not meant to be exhaustive of all the ongoing efforts, but I think that they highlight some key features and challenges of these institutions. Their probability of success in the longer term will certainly be affected by economic conditions but also by the ability of these newly emerging institutions to build a track record that establishes them as a permanent fixture that must be negotiated with in the local labor market. These challenges are not unfamiliar to unions. The key to the sur-

3. See table 9.2 for a summary of the programs discussed in this chapter along with their key features. 


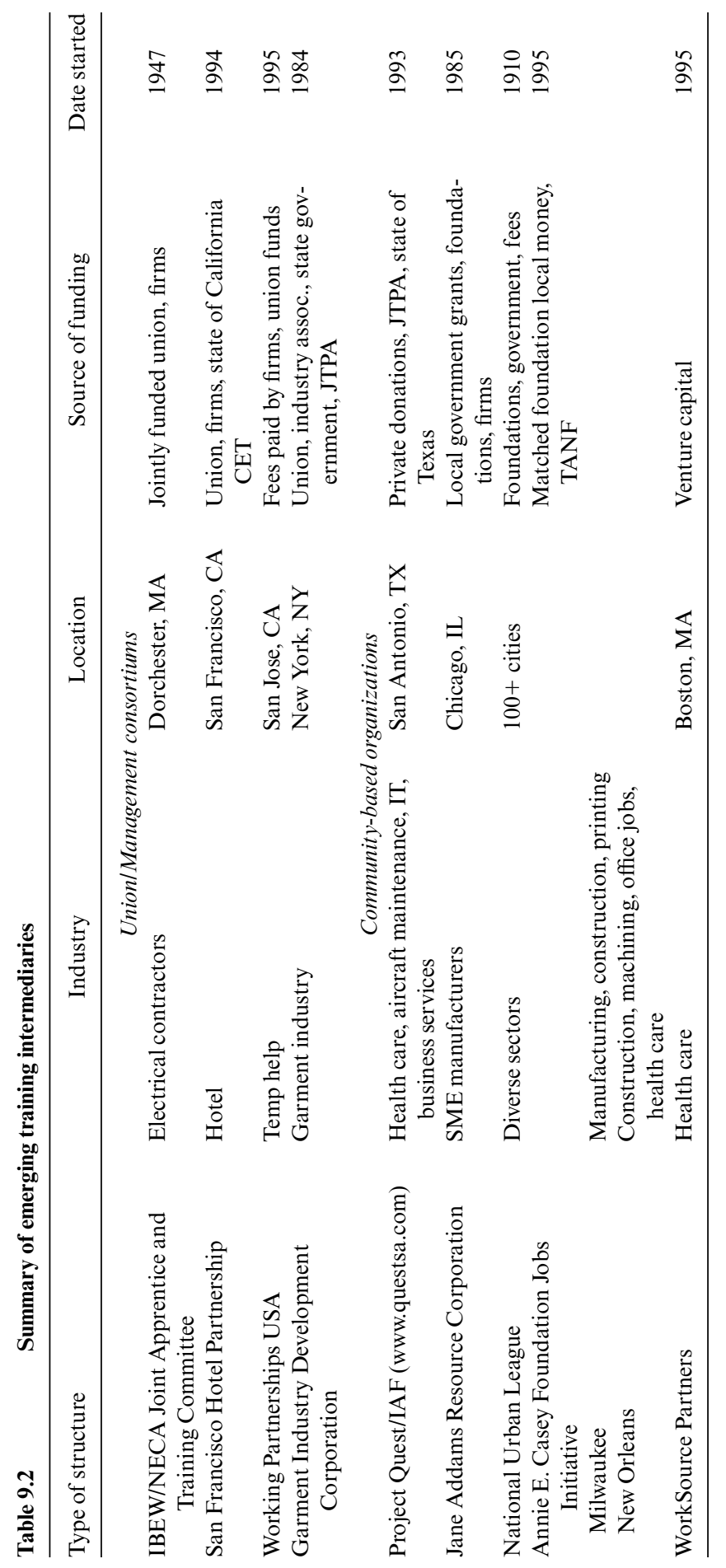


vival and impact of these organizations will be their ability to construct the social cohesion and common vision necessary to bring about the consensus that we see in other countries in a high training equilibrium.

\section{References}

Abt Associates and The New School for Social Research. 1999. Private interests, shared concerns: The relationship between employers and the AECF Jobs Initiative. Final report prepared for the Annie E. Casey Foundation. Baltimore, Md.: Annie E. Casey Foundation.

Acemoglu, Daron and Jorn-Steffen Pischke. 1998. The structure of wages and investment in general training. NBER Working Paper no. 6357. Cambridge, Mass.: National Bureau of Economic Research, January.

. 1999. Beyond Becker: Training in imperfect labor markets. Economic Journal 109:F112-F142.

American Federation of Labor-Congress of Industrial Organization (AFL-CIO) Working for America Institute. 2000. High road partnerships report. Washington, D.C.: AFL-CIO Working for America Institute.

Annie E. Casey Foundation. 2000. Stronger links: New ways to connect low-skilled workers to better jobs. Baltimore, Md.: Annie E. Casey Foundation.

Black, Sandra E., and Lisa M. Lynch. 2001. How to compete: The impact of workplace practices and information technology on productivity. Review of Economics and Statistics 83 (3): 434-45.

Booth, Alison, and Monojit Chatterji. 1998. Unions and efficient training. Economic Journal 108 (447): 328-43.

Brown, Rebecca, Evelyn Ganzglass, Susan Golonks, Jill Hyland, and Martin Simon. 1998. Working out of poverty: Employment retention and career advancement for welfare recipients. Available at [http://www.nga.org/Welfare/Employment Retention.htm].

Campbell, Brett. 1994. Investing in people: The story of Project QUEST. San Antonio, Tex.: Communities Organized for Public Service (COPS) and Metro Alliance. Available at [http://www.cpn.org/topics/work/quest6-7.html].

Cortés, Ernesto. 1994. Reweaving the social fabric. The Boston Review 19 (3). Available at [http://www.bostonreview.net/BR19.3/Cortes.html].

Donahue, John D., Lisa M. Lynch, and Ralph Whitehead Jr. 2000. Opportunity knocks: Training the commonwealth's workers for the new economy. Boston: MassINC.

Frazis, Harley J., Diane E. Herz, and Michael W. Horrigan. 1995. Employerprovided training: Results from a new survey. Monthly Labor Review 118 (5): 3-17.

Korshak, Stuart R. 2000. A labor management partnership: San Francisco's hotels and the employees' union try a new approach. Cornell Hotel and Restaurant Administration Quarterly 41 (2): 14-29.

Leuven, E., and Hessel Oosterbeek. 1999. Demand and supply of work-related training: Evidence from four countries. Research in Labor Economics 18:303-30.

Lynch, Lisa M. 1992. Private sector training and its impact on the earnings of young workers. American Economic Review 82 (1): 299-312.

Lynch, Lisa M., ed. 1994. Training and the private sector: International comparisons. Chicago: University of Chicago Press. 
Lynch, Lisa M., and Sandra E. Black. 1998. Beyond the incidence of employerprovided training. Industrial and Labor Relations Review 52 (1): 64-81.

Organization for Economic Cooperation and Development (OECD). 1997. Literacy skills for the knowledge economy. Paris: OECD.

Osterman, Paul, and Brenda Lautsch. 1996. Project QUEST: A report to the Ford Foundation. MIT, Sloan School of Management. Mimeograph.

Soskice, David. 1994. Reconciling markets and institutions: The German apprenticeship system. In Training and the private sector, ed. Lisa M. Lynch, 25-60. Chicago: University of Chicago Press.

Stevens, M. 1994. A theoretical model of on-the-job training with imperfect competition. Oxford Economic Papers 46:537-62.

Warren, Mark. 1996. Creating a multi-racial democratic community: A case study of the Texas Industrial Areas Foundation. Paper presented at conference, Social Networks and Urban Poverty. 1-2 March, New York. 